\title{
Correlation between Level of Soluble Suppression of Tumorigenicity-2 (sST2) with Global Longitudinal Strain (GLS) of Left Ventricle in Patients with Acute Myocardial Infarction
}

Dyah Adhi Kusumastuti*, Nahar Taufiq, Hasanah Mumpuni

\author{
Department of Cardiology and Vascular Medicine, Faculty of Medicine, Public Health and Nursing, Universitas Gadjah \\ Mada -Dr. Sardjito General Hospital, Yogyakarta, Indonesia \\ ${ }^{*}$ Corresponding Author: \\ Dyah Adhi Kusumastuti, MD, email : dyah.adhi.k@mail.ugm.ac.id \\ Department of Cardiology and Vascular Medicine, Faculty of Medicine, Public Health and Nursing, Universitas Gadjah \\ Mada - Dr. Sardjito Hospital Yogyakarta, Indonesia Jalan Farmako Sekip Utara, Yogyakarta, Indonesia 55281
}

Manuscript submitted: November 19, 2018; Revised and accepted: February 23, 2019

\section{ABSTRACT}

Background: Epidemiological data show that the incidence of heart failure after myocardial infarction is about $20 \%$. The incidence of heart failure after acute myocardial infarction is also known to increase post-infarct mortality. The incidence of heart failure is related to the remodelling process after acute myocardial infarction. The acute remodelling process after acute myocardial infarction involves a mechanical mechanism in which there is a change in left ventricular geometry as an adaptive response to the incidence of infarction and then results in increased left ventricular wall stress. Increased left ventricular wall stress can be assessed by measuring global longitudinal strain (GLS) using echocardiography. On the other hand, mechanical overload in the myocardium is known to increase sST2 levels. The relationship between increased levels of sST2 and left ventricular GLS in patients with acute myocardial infarction has never been studied before.

Methods: An analytic observational study with a cross-sectional design conducted from July to September 2018 at Dr Sardjito Hospital. Patients diagnosed with acute myocardial infarction and fulfilling the inclusion and exclusion criteria were included in the study. Measurement of sST2 levels and echocardiographic examination was performed on the first day after admission. Correlation test analysis was conducted to determine the relationship between sST2 levels and left ventricular GLS.

Results: There were 72 subjects, with 62 STEMI subjects and 10 NSTEMI subjects. The mean level of sST2 in this study was 4,252 $\pm 198 \mathrm{pg} / \mathrm{mL}$. Measurement of the left ventricular function obtained a mean ejection fraction of $47 \pm 9 \%$, LVIDd $45.79 \pm 6.2 \mathrm{~mm}$, and GLS values of $-9.3 \pm 3.3 \%$. Correlation test using Spearman test showed that there was no correlation between increased sST2 levels and decreased GLS values in patients with acute myocardial infarction $(r=-0.133 ; p=0.344)$.

Conclusion: Increased sST2 levels were not correlated with decreased GLS values in patients with acute myocardial infarction.

Keywords: soluble suppression of tumorigenicity 2; global longitudinal strain; acute myocardial infarct; post-infarctremodelling 


\section{INTISARI}

Latar Belakang: Data epidemiologi menyatakan angka kejadian gagal jantung pasca infark miokard sebesar 20\%. Kejadian gagal jantung pasca infark miokard akut juga diketahui meningkatkan mortalitas pasca infark. Kejadian gagal jantung berkaitan dengan proses remodeling pasca infark miokard akut. Proses remodeling akut pasca infark miokard akut melibatkan mekanisme mekanik dimana terjadi perubahan geometri ventrikel kiri sebagai respon adaptif terhadap kejadian infark dan kemudian mengakibatkan peningkatan stres dinding ventrikel kiri. Peningkatan stress dinding ventrikel kiri dapat dinilai dengan pengukuran global longitudinal strain (GLS) menggunakan ekokardiografi. Di sisi lain, overload mekanik pada miokardium diketahui menyebabkan peningkatan kadar SST2. Hubungan peningkatan kadar SST2 dengan nilai GLS ventrikel kiri pada pasien infark miokard akut belum pernah diteliti sebelumnya.

Metode Penelitian: Penelitian ini adalah studi observasional analitik dengan desain potong lintang yang dilakukan sejak Juli - September 2018 di RSUP Dr. Sardjito. Pasien yang terdiagnosis infark miokard akut dan memenuhi kriteria inklusi dan eksklusi dimasukkan ke dalam penelitian. Pengukuran kadar SST2 dan pemeriksaan ekokardiografi dilakukan pada hari pertama setelah admisi. Analisis uji korelasi dilakukan untuk mengetahui hubungan kadar sST2 dengan GLS ventrikel kiri.

Hasil: Didapatkan sampel sebanyak 72 subjek, dengan 62 subjek STEMI dan 10 subjek NSTEMI. Rerata kadar sST2 pada penelitian ini didapatkan $4.252 \pm 198 \mathrm{pg} / \mathrm{mL}$. Pengukuran fungsi ventrikel kiri didapatkan rerata fraksi ejeksi $47 \pm 9 \%$, LVIDd $45,79 \pm 6,2 \mathrm{~mm}$, dan nilai GLS sebesar $-9,3 \pm 3,3 \%$. Uji korelasi menggunakan uji Spearman didapatkan tidak ada hubungan antara peningkatan kadar sST2 dengan penurunan nilai GLS pada pasien infark miokard akut $(r=-0,133 ; p=0,344)$.

Simpulan: Peningkatan kadar sST2 tidak berhubungan dengan penurunan nilai GLS pada pasien infark miokard akut.

\section{INTRODUCTION}

Acute myocardial infarction (AMI) is defined as cardiac cell death due to prolonged ischemia as a result of an acute imbalance between oxygen supply and oxygen demand. ${ }^{1}$ Epidemiological data show the incidence of acute myocardial infarction with ST-segment elevation (STEMI) per year reaches 695,000 new cases with a mortality rate of around $14 \%$, while the incidence of heart failure after myocardial infarction is around $20 \%$. The incidence of heart failure after acute myocardial infarction is known to increase post-infarct mortality and morbidity. ${ }^{1}$

The left ventricular remodelling process is defined as molecular, cellular and interstitial changes in the myocardium due to injury to the myocardium, such as in acute myocardial infarction, which manifests as changes in size, mass, geometry and left ventricular function. Changes in left ventricular geometry due to the remodelling process after myocardial

infarction include thinning of the ventricular wall and dilatation of the left ventricle. ${ }^{2}$ This change in geometry results in increased ventricular wall stress as compensation. Continuous remodelling process can cause symptoms of heart failure. ${ }^{3}$ Global longitudinal strain (GLS) is known to be a predictor of remodelling events after acute myocardial infarction, GLS> $-10 \%$ to $-15 \%$ is known as a marker of high risk of ventricular remodelling after acute myocardial infarction. ${ }^{4}$

Suppression of Tumorigenicity 2 (ST2) is a member of the interleukin (IL) 
-1 receptor protein family with two transmembrane or cellular (ST2L) and soluble (sST2) main isoforms that can circulate in the serum. Biomarker SST2 is a protein similar to the interleukin (IL) 1 receptor, which levels increase in serum when the heart experiences mechanical stress. ${ }^{5}$ Experiments with increasing cardiac burden in vivo studies have been shown to cause elevations in both ST2 and soluble ST2 trans-membrane levels. In another in vivo study, the induction of myocardial infarction was shown to cause increased levels of SST2. ${ }^{6}$ Early studies in patients who experienced AMI proved that sST2 levels increased during infarct presentation and correlated linearly with serum creatinine kinase and inversely correlated with left ventricular function. ${ }^{7}$ SST2 levels were analysed in more than 800 patients with acute myocardial infarction with STsegment elevation (STEMI), it was found that SST2 levels at presentation correlated with mortality at treatment and 30 days after treatment. However, there have been no studies that have examined the association of SST2 levels with the initial phase remodelling parameters after AMI.

\section{METHODS}

This study was an analytic observational study with a crosssectional design. The sample of this study was AMI patients who were treated at Dr. Sardjito Hospital Yogyakarta between July and September 2018. The inclusion criteria in this study were patients with a diagnosis of AMI with an age range of 30-75 years with the onset of less than 72 hours. Exclusion criteria include: 1) Patients with a history of heart failure, 2) Patients with chronic renal failure, 3) Patients with hepatic cirrhosis, 4) Patients with concomitant pneumonia and/or acute exacerbations of chronic obstructive pulmonary disease during hospitalization, 5) Patients with sepsis during hospitalization, 6) Patients with malignancy, 7) Patients with aortic stenosis, 8) Patients with hypertrophic cardiomyopathy or left ventricle outflow tract (LVOT) obstruction, 9) The quality of echocardiographic images is not good enough for strain analysis.

We assessed patients with AMI who entered through the emergency room for their suitability with the study criteria. Demographic data, clinical profiles, electrocardiogram images, and laboratories were collected and recorded in the case report form. Demographic data are gender, age, smoking status, history of diabetes mellitus, hypertension, and chronic concomitant diseases namely chronic kidney disease, chronic heart failure, liver cirrhosis, chronic obstructive pulmonary disease and malignancy. Clinical profile data includes systolic blood pressure, diastolic blood pressure, heart rate frequency and Killip class values. Electrocardiogram images were obtained with 12 lead electrocardiogram devices, right leads (V2R, V3R and V4R) and posterior leads (V7, V8 and V9) and assessed during admission and hospital treatment. Routine laboratory data includes (1) routine blood tests namely hemoglobin, leukocyte numbers, leukocyte count, platelet counts, (2) examination of lipid profiles namely: triglyceride concentrations, HDL cholesterol, total cholesterol and LDL cholesterol, (3) examination of kidney function: urea and creatinine (4) glucose examination when and (5) examination of cardiac enzymes, namely: CK-MB and HsTrop I (if serially needed). Blood specimens for sST2 measurement were takenwithin the first 24 hoursthen processed for serum isolation. The serum is inserted in a microtube and stored in a freezer with a temperature of $-80^{\circ} \mathrm{C}$ until SST2 quantification. Transthoracic echocardiography was also performed within the first 24 hours with VIVID S6 (General Electric, American) or HD 15 (Philip, Netherlands). If an intervention 
is performed or new myocardial infarction happens between taking blood specimens with transthoracic echocardiography examination, the sample will be excluded. We measured GLS using speckle-tracking method, which is carried out using the standard EchoPAC program by two observers who are blind to clinical data. Longitudinal strain analysis was carried out on the apical 4-chamber window, apical 2-chamber and apical 3chamber. At each inspection window, the program will determine the border of the myocardium automatically. If it is felt that the automatically determined myocardium limit is not suitable, then the myocardium border will be determined manually. The GLS value is determined by taking the average value of the longitudinal strain from the three apical windows.Soluble ST2 level was quantified by quantitative sandwich enzyme immunoasay technique using R\&D systems ELISA kit (Abington, United Kingdom).

Statistical analysis used the version 20 Statistical Package for Social Sciences (SPSS) software for the Windows operating system. Basic characteristics data on numerical scale variables will be presented in the form of average values and standard deviations. Data with categorical variables will be presented as a percentage. Data from independent variables and dependent variables are assessed whether they are normally distributed or not.Hypothesis testing of the correlation between independent variables (sST2) and the dependent variable (left ventricular strain) will be analysed using Pearson if the data distribution is normal or Spearman if the distribution is not normal. Statistically significant results when $p<0.05$.

\section{RESULTS}

This study was conducted from July 2018 to September 2018 in Dr. Sardjito Hospital. During this period there was a total population of $87 \mathrm{AMI}$ patients. Fifteen subjects were excluded, five subjects due to heart failure, two subjects due to a history of chronic kidney failure, two subjects due to chronic pulmonary obstructive disease, two subjects due to sepsis and four subjects because echocardiographic data could not be analysed. So the total sample was 72 subjects with baseline characteristics are as shown in table 1.

Sixty-two $(86.1 \%)$ subjects were diagnosed with STEMI. Fifty-nine (82\%) subjects came with Killip I, and 50 $(69.4 \%)$ subjects were revascularized. Echocardiographic data showed: mean ejection fraction of $47 \pm 9 \%$, mean LVIDd of $45.79 \pm 6.2 \mathrm{~mm}$; mean LVEDV was $78 \pm 29 \mathrm{ml}$, mean LVESV was $42 \pm 19 \mathrm{ml}$. Mean sST2 level of $4,252 \pm 198 \mathrm{pg} / \mathrm{mL}$, while mean GLS of $-9.3 \pm 3,3 \%$.In the analysis of the correlation analysis of SST2 levels with GLS, we find a negative correlation with $r=-0.133, p=0.344$ (figure 1).

\section{DISCUSSION}

The mean sST2 levels in this study were obtained at 4,252 $\pm 198 \mathrm{pg} /$ $\mathrm{mL}$ with the highest value of $4,525 \mathrm{pg} /$ $\mathrm{mL}$ and the lowest value of $3,793 \mathrm{pg} /$ $\mathrm{mL}$. The level of sST2 in this study increased when compared to normal values in healthy individuals. The normal value of SST2 in healthy individuals is known to be 6.7-20.4 pg / $\mathrm{mL}$. In a study in STEMI, sST2 levels increase beyond normal values from 6 18 hours since the onset of infarction. ${ }^{8}$ The study conducted by Weinberg in 69 AMI patient subjects it was found that sST2 levels increased on the first day after AMl with an average of SST2 levels of $3.8 \pm 0.4 \mathrm{ng} / \mathrm{mL}$ with a maximum value of $0.32 \mathrm{ng} / \mathrm{mL}$ and a maximum value of $17.42 \mathrm{ng} / \mathrm{mL}{ }^{6}$ The GLS value in this study obtained an average of $-9.3 \pm 3.3 \%$ with a maximum value of $-16.6 \%$ and a minimum value of $-3.1 \%$. 
Table 1. Basic characteristics

\begin{tabular}{|c|c|}
\hline Parameters & Value \\
\hline \multicolumn{2}{|l|}{ Gender } \\
\hline Male; n (\%) & $56(77.8)$ \\
\hline Age (year); mean \pm SD & $58.71 \pm 13.00$ \\
\hline \multicolumn{2}{|l|}{ Diagnosis } \\
\hline STEMI; n (\%) & $62(86.1)$ \\
\hline NSTEMI; n (\%) & $10(13.9)$ \\
\hline Onset (hour); mean \pm SD & $9.4 \pm 8.0$ \\
\hline \multicolumn{2}{|l|}{ Killip class } \\
\hline Killip I; n (\%) & $59(82.0)$ \\
\hline Killip II; n (\%) & $8(11.0)$ \\
\hline Killip III; n (\%) & $3(4.2)$ \\
\hline Killip IV; n (\%) & $2(2.8)$ \\
\hline \multicolumn{2}{|l|}{ Revascularisation } \\
\hline Revascularized; n (\%) & $50(69.4)$ \\
\hline \multicolumn{2}{|l|}{ Risk Factor } \\
\hline Diabetes Mellitus; n (\%) & $20(28)$ \\
\hline Hypertension; n (\%) & $43(60)$ \\
\hline Smoker; n (\%) & $33(46)$ \\
\hline Dyslipidemia; n (\%) & $30(43)$ \\
\hline \multicolumn{2}{|l|}{ Therapy } \\
\hline Aspilet; n (\%) & $72(100)$ \\
\hline \multicolumn{2}{|l|}{$\mathrm{P}_{2} \mathrm{Y}_{12}$ Inhibitor; $\mathrm{n}(\%)$} \\
\hline Clopidogrel & $52(72)$ \\
\hline Ticagrelor & $20(28)$ \\
\hline \multicolumn{2}{|l|}{ Anti-remodelling; n (\%) } \\
\hline ACE-I + bisoprolol & $33(46)$ \\
\hline ACE-I & $20(28)$ \\
\hline ARB + bisoprolol & $2(3)$ \\
\hline ARB & $3(4)$ \\
\hline Bisoprolol & $3(4)$ \\
\hline No therapy & $11(15)$ \\
\hline Statin; n (\%) & $72(100)$ \\
\hline \multicolumn{2}{|l|}{ Echocardiography Parameter } \\
\hline Ejection fraction $(\%)$; mean \pm SD & $47 \pm 9$ \\
\hline LVIDd $(m m) ;$ mean \pm SD & $46 \pm 6$ \\
\hline LVEDV (ml); mean \pm SD & $78 \pm 29$ \\
\hline LVESV $(\mathrm{ml}) ;$ mean \pm SD & $42 \pm 19$ \\
\hline GLS (\%); mean \pm SD & $-9.3 \pm 3.3$ \\
\hline Hs Trop I ; mean \pm SD & $14.128 \pm 16.683$ \\
\hline Soluble ST2 $(\mathrm{pg} / \mathrm{mL}) ;$ mean \pm SD & $4,252 \pm 198$ \\
\hline
\end{tabular}

The normal value of GLS according to the American Society of Echocardiography and the European Association of Cardiovascular Imaging is $-20 \%$ with a range between $-17.3 \%$ to $-21.5 \% .{ }^{9}$ So the GLS value obtained in this study is lower than the normal value in healthy individuals. The result is consistent with various studies of GLS in the AMI population. The study conducted by Antoniet et al. in the subject population of acute myocardial infarction with the entire subject of 341 patients with acute myocardial infarction performed by primary $\mathrm{PCl}$, the mean value of GLS $-13.7 \pm 3.3 \%$, with echocardiographic examination performed at 48 hours from admission. ${ }^{10}$ 


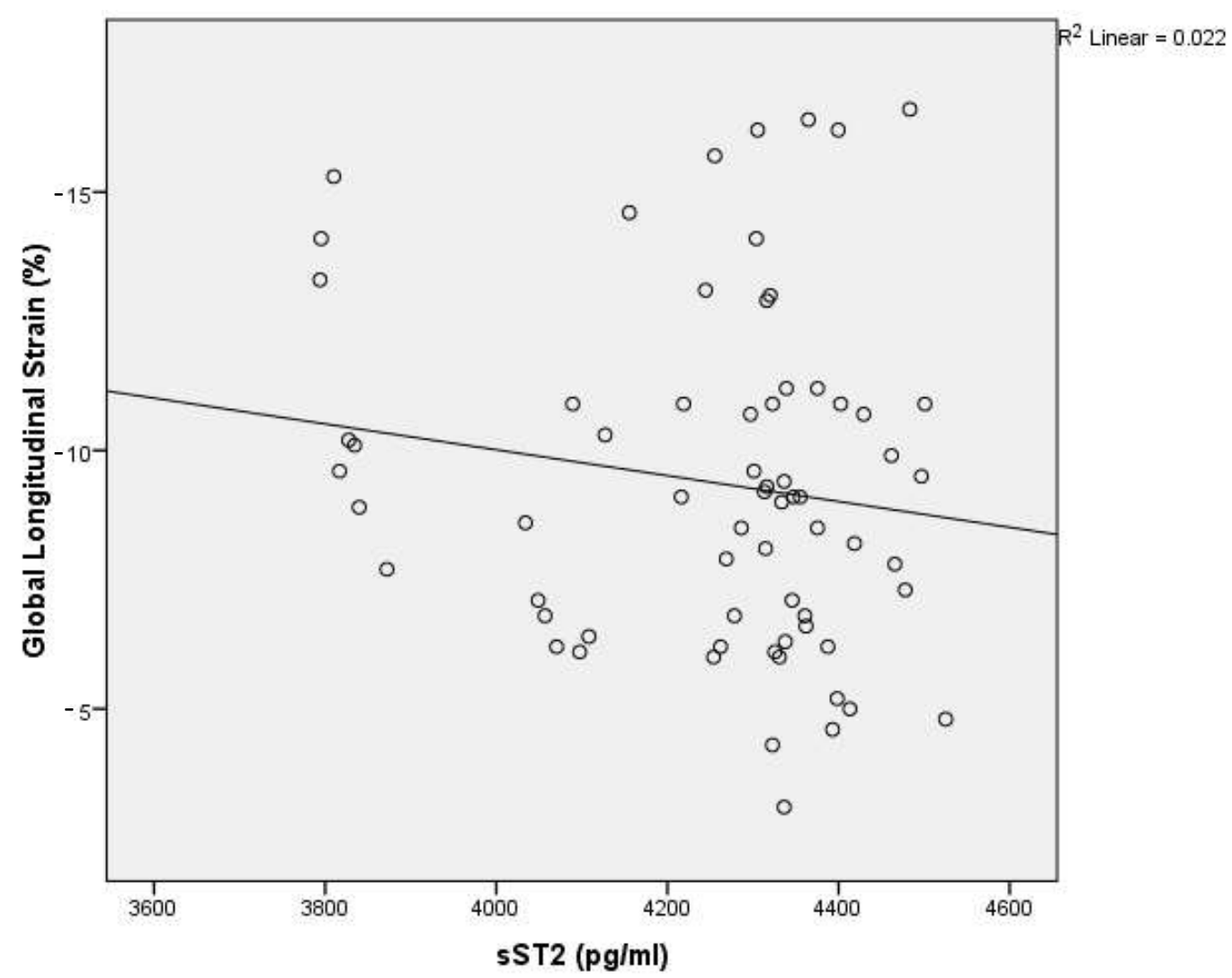

Figure 1. Scatter-plot correlation between SST2 and GLS in patients with acute myocardial infarction $(r=-$ $0.113, p=0.344)$

The study conducted by Aniyathodiyil et al. in 50 subjects with STEMI who were revascularized with primary $\mathrm{PCl}$ and performed echocardiography before the primary $\mathrm{PCl}$ action, the mean of GLS was $12.41 \pm 2.95 \%{ }^{12}$ Decreased GLS values as found in this study and previous studies illustrate an increase in left ventricular strains after AMI. The mean value of GLS obtained in this study was lower than the GLS value in the previous study, possibly due to echocardiography in this study carried out at 24 hours of treatment, regardless of the revascularisation performed.

From the correlation test conducted on sST2 levels and GLS values in patients with AMI, no relationship was found between the two variables. The incidence of AMI will begin a series of remodelling processes in the left ventricle that initially are adaptive responses to decreased left ventricular function due to myocardial infarction. One of the early phase remodelling processes is the occurrence of mechanical changes in contraction of the left ventricle due to shifting of myocytes after infarction, which then increases the stress of the left ventricular wall and causes deformation of the myocardium and an increase in left ventricular strains measured by decreased GLS. The initial phase remodelling process also occurs at the cellular level where the death of heart muscle cells will trigger the inflammatory process as part of the process of healing the left ventricle after acute myocardial infarction. One of the cells involved is fibroblast cells, which will be activated and proliferate and in the later phase of the remodelling process will form fibrosis tissue. ${ }^{2}$ Soluble ST2 is known to be produced by cardiomyocytes and is a feed receptor from IL-33.

Whereas cardiac fibroblast cells are known to produce IL-33 under the 
conditions of mechanical strains, in which IL-33 plays a role in inhibiting the occurrence of myocardial hypertrophy and fibrosis when binding to the transmembrane ST2 receptor. When sST2 levels in serum are high, SST2 will be a competitor receptor of the ST2 receptor found in transmembrane. The bond between IL-33 and SST2 will eliminate the protective effect on the myocardium. ${ }^{13,14}$

So there is no correlation between the increase in SST2 levels and the decrease in GLS in this study whether due to an increase in SST2 levels more due to myocardial fibrosis compared to the increase in mechanical stress after acute myocardial infarction. ${ }^{15}$ The statement was supported by previous studies which concluded that SST2 levels were positively correlated with infarction volume index $(r=0.26 ; p=0.023)^{16}$ and good infarct area at 1 week post AMI $(r$ $=0,41 ; p<0.001$ ) and 6 months post AMI $(r=0.50 ; p<0.001) .{ }^{17}$ However, this study did not examine fibrosis markers to determine whether sST2 levels were correlated with fibrosis in post-AMI myocardial.

Until now, there have been no studies that have examined changes in sST2 levels over time so that the pattern of changes in SST2 levels after AMI has not been known over time. Research by Weinberg et al. in 69 subjects with AMI patients it was found that SST2 levels increased on the first day after AMI. ${ }^{6}$ The research conducted by Sabatine et al. in the STEMI population, measuring SST2 levels at the time of admission of patients in the emergency department as baseline measurements and at the time of angiography (average 4 days after admission), the results of SST2 levels at angiography were lower than baseline, but remain higher than normal values. ${ }^{14}$ Research by Weir et al. measured sST2 levels in the AMI population three times, first at baseline, i.e. 7-14 days after AMI onset, second at 12 weeks after baseline and third at 24 weeks after baseline. The level of SST2 was found to remain high at 24 weeks measurement but decreased significantly compared to baseline levels, with the most decrease occurring between baseline levels and 12 weeks evaluation. ${ }^{16}$

These studies show that SST2 levels will increase since the onset of AMI onset and remain high for weeks after AMI. Remodelling parameters in these studies were measured in the further phase of remodelling, which averaged six months after AMI. From these studies, it is known that SST2 levels are correlated with the incidence of advanced phase remodelling after AMI. While in this study the measurement of SST2 levels and measurement of acute phase remodelling parameters, namely GLS parameters, were cross-sectional in the first 24 hours after AMI.

In this study, taking blood specimens for measuring sST2 levels and echocardiographic examinations to assess GLS was also not done at the same time. The absence of correlation between the increase in SST2 value and the incidence of acute phase postAMI remodelling which is characterised by a decrease in GLS in this study, probably because the post-AMI remodelling process is a series of processes starting from the onset of $\mathrm{AMI}$ and can last for months after AMI. ${ }^{18}$ So further research might be needed to examine the relationship of sST2 levels with the longitudinal stages of the post-AMI remodelling process.

The post-AMlremodelling process is an ongoing process that starts after an AMI event and can last for months after the AMI event. ${ }^{18}$ Whereas this research was conducted in a cross-sectional design, which only took data at one time only at 24 hours post-AMI so that it became a limitation of this study because it could not describe the remodelling process as a whole. Another limitation of this study is that this study did not assess fibrosis markers,so it was not known whether 
the post-AMI fibrosis process was correlated with an increase in SST2 levels in patients with $\mathrm{AMI}$ and this might be investigated in future studies.

\section{CONCLUSION}

Increased SST2 levels were not correlated with a decrease in left ventricular GLS in patients with acute myocardial infarction.

\section{REFERENCES}

1. Gerber Y., Weston S.A., Enriquez-Sarano M., Manemann S.M., Chamberlain A.M., Jiang R., et al. 2016. Atherosclerotic burden and heart failure after myocardial infarction. JAMA Cardiol, 1:156162.

2. Sutton M.G., Sharpe N. 2000. Left ventricular remodeling after myocardial infarction pathophysiology and therapy. Circulation, 101:2981-2988.

3. Azevedo P.S., Polegato B.F., Minicucci M.F., Paiva S.A.R., Zornoff L.A.M. 2016. Cardiac remodeling: concepts, clinical impact, pathophysiological mechanisms and pharmacologic treatment. Arq Bras Cardiol, 106:62-69.

4. Zaliaduonyte-Peksiene D., Simonyte S., Lesauskaite V., Vaskelyte J., Gustiene O., Mizariene V., et al. 2014. Left ventricular remodelling after acute myocardial infarction: Impact of clinical, echocardiographic parameters and polymorphism of angiotensinogen gene. J ReninAngiotensin-Aldosterone Syst, 15:286-293.

5. Miller A.M., Liew F.Y. 2011. The IL-33/ST2 pathway - A new therapeutic target in cardiovascular disease. Pharmacol Ther, 131:179-186.

6. Weinberg E.O., Shimpo M., De
Keulenaer G.W., Macgillivray C., Tominaga S., Solomon SD., et al. 2002. Expression and regulation of ST2, an interleukin-1 receptor family member, in cardiomyocytes and myocardial infarction. Circulation, 106:2961-2967.

7. Shimpo M., Morrow D.A., Weinberg E.O., Sabatine M.S., Murphy S.A., Antman E.M., et al. 2004. Serum levels of the interleukin-1 receptor family member ST2 predict mortality and clinical outcome in acute myocardial infarction. Circulation, 109:2186-2190.

8. Richards A.M., Di Somma S., Mueller, T. 2015. ST2 in stable and unstable ischemic heart diseases. Am J Cardiol, 115(7 Suppl):48B-58B.

9. Lang R.M., Badano L.P., MorAvi V., Afilalo J., Armstrong A., Ernande L., et al. 2015. Recommendations for cardiac chamber quantification by echocardiography in adults: an Update from the American Society of Echocardiography and the European Association of Cardiovascular Imaging. J Am Soc Echocardiogr, 28:1-39.

10. Antoni M.L., Mollema S.A., Atary J.Z., Borleffs C.J.W., Boersma E., Van De Veire N.R.L., et al. 2010. Time course of global left ventricular strain after acute myocardial infarction. Eur Heart J, 31:20062013.

11. Mele D., Nardozza M., Chiodi, E. 2017. Early speckle - tracking echocardiography predicts left ventricle remodeling after acute ST -segment elevation myocardial infarction. J Cardiovasc Echogr, 27:93-98.

12. Aniyathodiyil G., Bohra S.S., Mottengar A., Govind S.C. $2017 . \quad$ Speckle-tracking echocardiography to assess global and regional left 
ventricular function in acute myocardial infarction. J Indian Acad Echocardiogr Cardiovasc Imaging, 1:177-184

13. Sanada S., Hakuno D., Higgins L.J., Schreiter E.R., Mckenzie A.N.J., Lee R.T. 2007. IL-33 and ST2 comprise a critical biomechanically induced and cardioprotective signalling system. J Clin Invest. 117:1538-1549.

14. Sabatine M.S., Morrow D.A., Higgins L.J., MacGillivray C., Guo W., Bode C., et al. 2008. Complementary roles for biomarkers of biomechanical strain ST2 and N-terminal prohormone B-type natriuretic peptide in patients with STelevation myocardial infarction. Circulation, 117:1936-1944.

15. Sanchez-Mas J., Lax A., Asensio-Lopez M.C., PascualFigal D.A. 2014. Modulation of IL-33/ST2 system in postinfraction heart failure: correlation with cardiac remodelling markers. Eur J Clin Invest, 44:643-651.

16. Weir R.A.P., Miller A.M., Murphy G.E.J., Clements S., Steedman T., Connell J.M.C., et al. 2010. Serum soluble ST2 a potential novel mediator in left ventricular and infarct remodeling after myocardial infarction. J Am Coll Cardiol, 55:243-250.

17. Minana G., Nunez J., BayesGenis A., Revuelta-Lopez E., Rios-Navarro C., Nunez E., et al. 2018. ST2 and left ventricular remodeling after st-segment elevation myocardial infarction: a cardiac magnetic resonance study. Int J Cardiol, 270:336342.

18. D'Elia N., D'hooge J., Marwick T.H. 2015. Association between myocardial mechanics and ischemic LV remodeling. JACC: Cardiovasc Imaging, 8:14301443. 